\title{
Governments urged to rethink dam projects
}

Mark Schrope

The environmental and social cost of major dam projects around the world has been unacceptably high, even though many of them have provided significant economic benefits, says a global assessment that is expected to influence future consideration of dam developments.

The World Commission on Dams, which released its report in London last week, proposes new frameworks for deciding whether dam projects are really needed and for planning those that do proceed.

The report has been welcomed by ecologists and health researchers, many of whom have criticized national governments and agencies such as the World Bank for ploughing ahead with large dam projects in the face of environmental objections. "It represents a unique body of knowledge that has not been accessible before," says Adrian Sleigh, a researcher into tropical public health at the University of Queensland in Brisbane.

The commission is an international 12-member panel representing such diverse interests as commercial dam builders, indigenous peoples and environmental organizations. It functions independently, but is sponsored by the World Bank and other interested organizations.

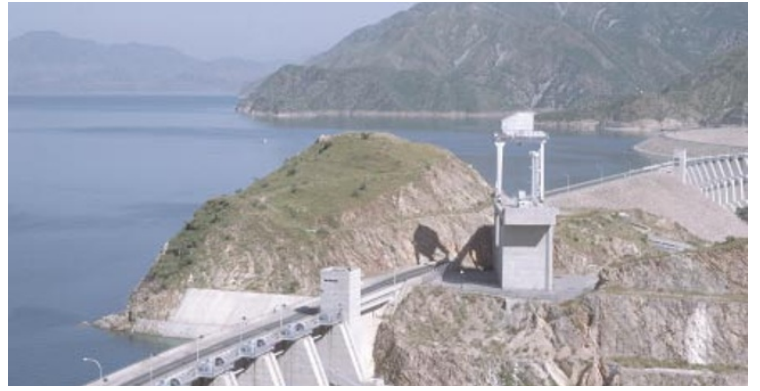

Damning verdict: the World Commission on Dams has found that the social and environmental costs of projects such as Pakistan's Tarbela dam, shown here, can sometimes outweigh their economic benefits.

It estimates that the 45,000 large dams around the globe have cost over $\$ 2$ trillion to build and are responsible for about $20 \%$ of the world's power and 15\% of its food supply. The report says that although dams can have positive ecological effects, such as establishing new wetland habitats, their overall effect on the environment has been negative because of loss of habitat, species reductions and other problems. In addition, dams have displaced between 40 million and 80 million people from their homes.

Deborah Moore, a member of the commission and a consulting scientist with Environmental Defense, a non-profit organization based in New York, says that few of the dams have been properly evaluated on their performance in producing energy, controlling floods or delivering water supplies.
But the commission's study suggests that large dams have typically not met their intended goals.

The report calls for long-term monitoring of dam performance to maximize efficiency and reduce harmful effects. And it strongly urges planners to consider potential alternatives to dams, such as better management of existing resources and interconnection of power grids.

The commission adds that when dam projects do proceed, social and environmental effects should be considered just as important as economic ones - in contrast to current standard practice. It also urges that people affected by projects be allowed to participate in planning, and that developers should be held contractually accountable for accomplishing agreed goals.

\section{Aventis gets short shrift over release of modified corn}

Jessa Netting, Washington

The US government looks unlikely to bow to demands from Aventis that it temporarily approve the company's genetically modified StarLink corn for human consumption, following the inadvertent and embarrassing release of the strain into the food chain.

The US Environmental Protection Agency (EPA) appears unimpressed by data submitted in support of the request by Aventis, the North Carolina-based manufacturer of the corn. The EPA's preliminary evaluation questioned the company's interpretation of studies on the potential for allergic reactions to the corn.

The EPA made its assessment in preparation for a public meeting near Washington on 28 November at which it will solicit comment from the public and from a panel of scientists. The regulatory agency will receive the panel's final recommendations on 1 December.

A coalition of US environmental groups concerned about genetically engineered foods initiated the furore in mid-September when their tests found traces of StarLink DNA in taco shells. The discovery led to a massive recall of more than 300 food brands.
The submission of new data is part of a petition by Aventis to allow StarLink corn to be present temporarily in processed foods, to avoid more recalls of products already on the market, says a company representative.

Debate over this strain of corn has been heated. The strain, approved in 1998 for use in animal feeds, is engineered to produce an insecticidal protein related to others already in widespread use. But the protein, Cry9C, does not break down at certain

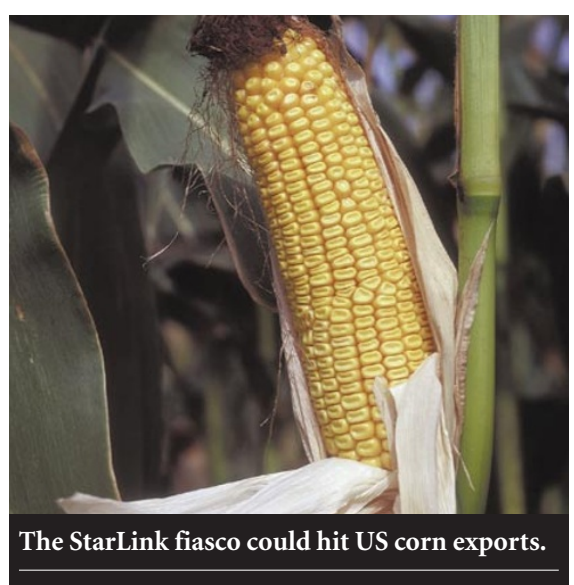

ش ๔ 2000 Macmillan Magazines Ltd temperatures and conditions, which has caused alarm about its potential to trigger human allergies.

Despite these concerns, an Aventis spokesman says the company is convinced that StarLink will not cause allergic reactions. Another Aventis representative, Rhonda Barnat, adds: "This is a technical regulatory issue, not a product safety issue."

The EPA has criticized the company's analysis of the new data. EPA official Stephen Johnson says: "We don't think they have provided us with sufficient information [on the allergy issue]." The EPA also finds fault with the way Aventis determines allergic potential and uses peanut protein, a potent allergen, as a measure of safety.

"It is clear that the company violated its licence and that is an outrage to us," says Johnson, adding that the agency needs to review the new information further before making any final decisions.

Taiwan also reports finding StarLink in corn grits, says Tim Galvin, an official at the US Department of Agriculture's Foreign Agricultural Service. And Japan has found the variety, which it had not approved, in $\mathbf{1 0}$ of 15 samples of a baking product. 